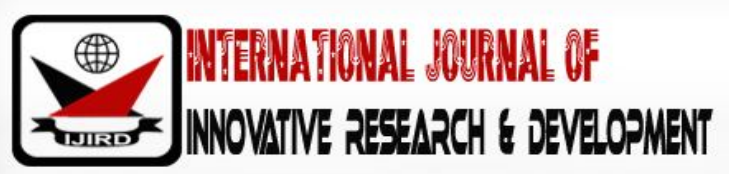

ISSN 2278 - 0211 (Online)

\section{A Survey of Water Sources for Households around the Yankari Game Reserve, Nigeria}

\author{
Salamatu J. Fada \\ School of Environment, Natural Resources and Geography, Bangor University, UK \\ Daniel D. Dabi \\ Department of Geography \& Planning, University of Jos, Nigeria \\ Naziru Z. Muhammed \\ Yankari Game Reserve, Bauchi State, Nigeria
}

\begin{abstract}
:
In the second half of the 20th century, the decline in rainfall from the early 1970s to the mid-1990s caused a 25$35 \mathrm{~km}$ shift southward in the West African savannah ecological zones, resulting inwater stress experienced in this region. Further compoundingthe water stress is other factors such asthe extent to which the water is potable and accessible. These conditions are worse,particularly, in rural communities in northern Nigeria. This study surveys thesources of water supply for households around the Yankari Game Reserve, Nigeria (Yankari). A field survey, (using focus group discussions and questionnaire survey of 122 households were conducted in five local communities (Dagudi, Galen sanji, Jada, Yalo and Pali) in Yankari to explore sources and uses of water in the area. Major findings suggest that the Gaji River has the most potential as the main source of water for domestic uses and animal watering as reported by $75 \%$ of the households surveyed. It is also the main source of water for animals and plants in the park. Other sources of water with potentials include four warm water springs: Wikki, Dimmil, Gwana and Mawulgo springs. Tungan Naliki is the fifth spring and the onlycool spring in Yankari. The Wikki warm spring is the largest and only water spring that has been explored. However, the Yankari communities do not have immediate access to the Wikki spring neither do they have any tap water connection, Rather, they rely on hand dug wells, bore holes and direct rainfall collection during the rainy season but suffer adverse scarcity of water in the dry season. Nevertheless, the Gaji River and the Yankari water springs are potential sources of water for the surrounding localcommunities. The study recommends further studies on the quantity and quality of water from these sources.
\end{abstract}

Keywords: Water stress, local communities, water sources, river and springs, portable water, accessible, potential source

\section{Introduction}

In West Africa, the long-term decline in rainfall amount and duration from the 1970s to the 1990s caused a 25-35km shift southward in the Sahel, Sudan and Guinean ecological zones in the 20th century (Gonzalez, 2001). Although there are adequate surface and ground water resources to meet current demands for potable water in Nigeria, the distribution of water in both temporal and spatial terms have led to scarcity in some locations, especially in northern Nigeria(FGN, 2000). Additionally, the decline in rainfall has also contributed to the water stress experienced by about $25 \%$ of the population, while $69 \%$ live under conditions of relative water abundance (Vörösmarty et al., 2005). However, this relative abundance does not take into account other factors such as the extent to which the water is potable and accessible, and the availability of sanitation. These conditions are even worse in rural communities in the northern part of Nigeria where water shortages are common with attendant potential for conflicts (FGN, 2000, Dabi et al, 2008). Therefore, there is the need to develop alternative sources of water supply for the inhabitants of the area. This paper presents results of a survey of sources of water available for households around the Yankari Game Reserve, Nigeria

\section{Study area}

Nigeria covers a land area of about $924,000 \mathrm{~km}^{2}$ spanning across climatic conditions varying between semi-arid in the north (with average rainfall ranges from about $500 \mathrm{~mm} /$ year) to tropical and humid in the south (with more than 2,000 $\mathrm{mm}$ / year of rainfall). Most rainfall occurs in well-defined rainy seasons of four to five months (May to September) in the north 
and six to seven months (April to October) in the south. These climatic conditionshave given rise to six ecological zones (Swamps forest, rainforest, Guinea Savannah, Sudan Savannah, Sahel Savannah, Montane vegetation of the Jos, Mambila and Obudu Plateaus)defined by the nature of vegetation. This landscape is dissected by drainage system made up of numerous rivers. The main rivers, Niger and Benue, converge at a confluence in the central part of the country flowing southwards as the river Niger and draining into the Atlantic Ocean in the extensive Niger delta area. Major tributaries to the Niger and Benue as well as other rivers are perennial and serve as sources of water supply for agriculture and domestic uses(Okwa, Akinmolayan, Carter, \& Hurd, 2009).

This survey was carried out in the Yankari Game Reserve (Yankari) located in Bauchi State, north-eastern part of Nigeria (see Figure 1). It covers a total land area of 2,244 $\mathrm{km}^{2}$ mostly situated within the Sudan savanna ecological zone of the country (Fada, 2015).The Gaji River, aperennial stream, traverses Yankari. Other water bodies within the game reserve area include four warm water springs, the Wikki, Dimmil, Gwan and Nawulgo springs. Tungan Naliki is the fifth but is the only cool spring in the area. The Wikki warm spring is the largest and only water spring that has been explored.

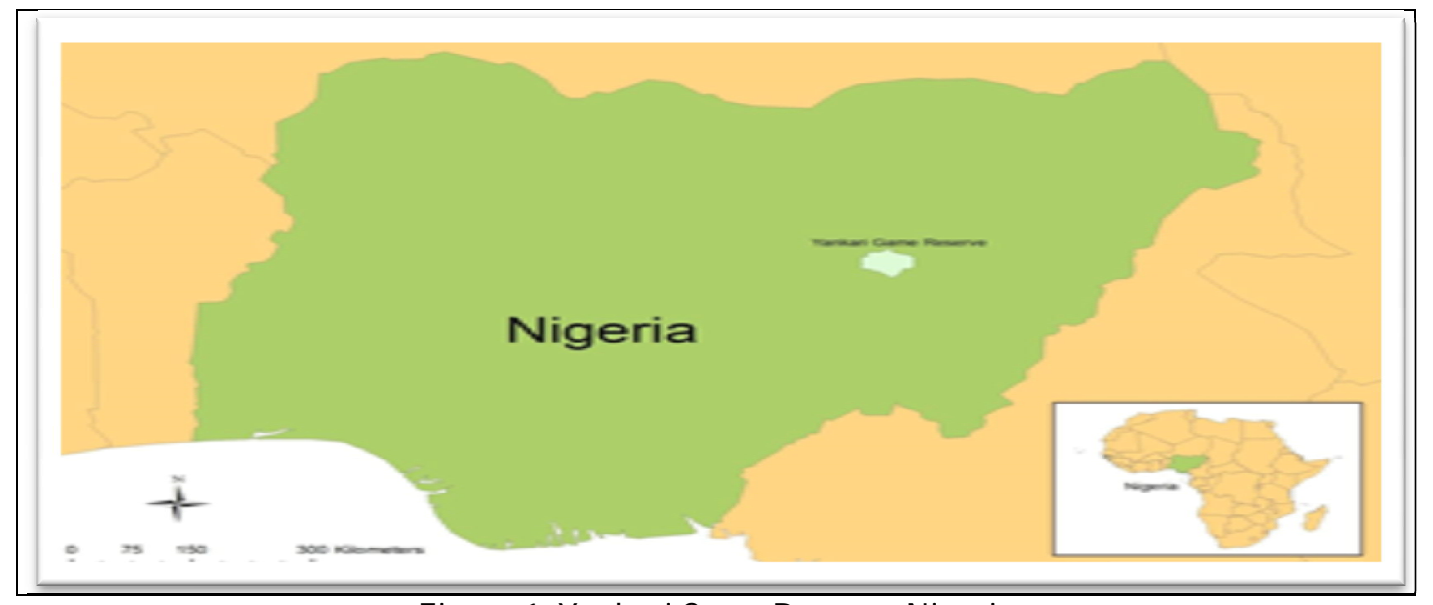

Figure 1: Yankari Game Reserve, Nigeria

\section{Materials and Methods}

This survey was carried out in five localcommunities (Dagudi, Galen sanji, Jada, Yalo and Pali) of Yankari using the following survey methods:

- $\quad$ Field survey using GPS sets, measuring tapes, and a camera. Information obtained included maps, watering points, location of the springs, and pictures of these water bodies;

- $\quad$ Focus group discussions (FGDs) were also conducted with selected stakeholders (including a community leader and representatives of households to give a total of ten (10) people in each community.

- $\quad$ A questionnaire survey was also carried out in which copies were administered on 122 households in Yankari (see Plate 1). Information was solicited on current sources water and quantities of water collected for domestic use (drinking, cooking, sanitary purposes, ablution, among others) as well as potential sources of water in the area that can be used for domestic purposes and even agricultural (animal watering and irrigation) and industrial (like brick making, pottery etc.).

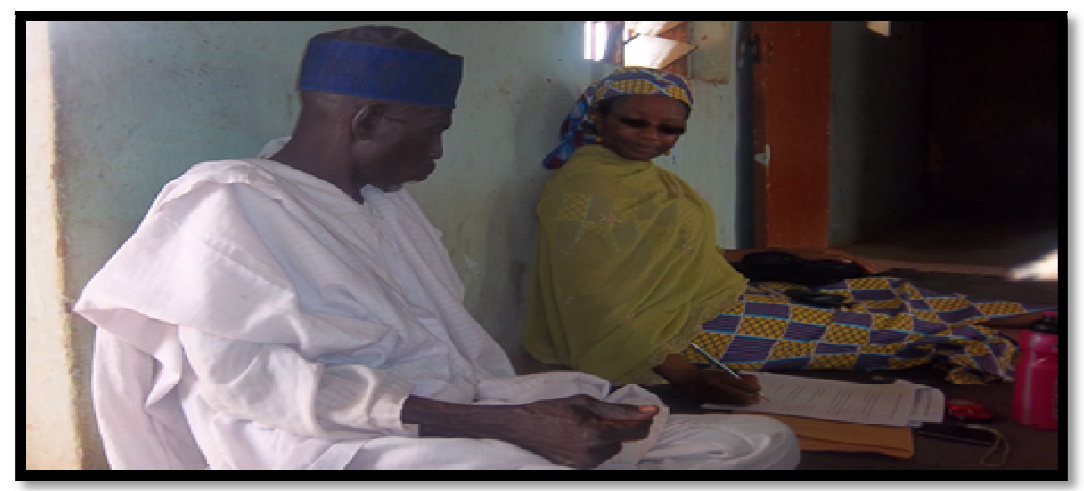

Plate 1: Questionnaire Survey in Pali 


\section{Results}

The Gaji River is the main source water of domestic uses and animal watering in the area. A total of $75 \%$ of the households surveyed indicated that they get their water from the Gaji River. The river is also the main source of water for animals and plants in the park. The field survey revealed that there are other sources of water in the area. These are the four warm water springs, the Wikki, Dimmil, Gwan and Nawulgo springs. The fifth and only cool spring in the area is the Tungan Naliki spring. The location of these water bodies is presented in Table 1 which shows the coordinates of the GPS points taken during the survey. Of all five springs, Wikki warm spring is the largest and only water spring that has been explored and developed (see Plate 2). The Wikki spring is about 13.0 metres wide and 1.9 metres deep. The daily flow of water is about $21,000,000$ litres. The water is very clear and free of any physical property contamination and drains into the Gaji River. The Wikki spring has a near constant temperature of $31.1^{\circ} \mathrm{C}$ all year round at day and night and serves as tourist and recreational site. The quality of water in the Wikki spring is very high and can be used without major purification for physical and biological and chemical properties contamination.

\begin{tabular}{|c|c|c|c|}
\hline \multirow[t]{2}{*}{ S/ No } & \multirow[t]{2}{*}{ Water Bodies (surface) } & \multicolumn{2}{|c|}{ Coordinates (GPS points) } \\
\hline & & Northings & Eastings \\
\hline 1 & Gaji River & N090 43' 19.4" & E0 $10030^{\prime} 46.5^{\prime \prime}$ \\
\hline 2 & Gwana Spring & N09 $040^{\prime} 22.5^{\prime \prime}$ & E0 $10029^{\prime} 57.0^{\prime \prime}$ \\
\hline 3 & Dimil Spring & N09 0 39'40.2" & E0 $10029^{\prime} 37.8^{\prime \prime}$ \\
\hline 4 & Mawulgo Spring & N09 $048^{\prime} 00.8^{\prime \prime}$ & E0 $10033^{\prime} 48.6^{\prime \prime}$ \\
\hline 5 & Tungan Maliki Spring & N09 0 47' 52.6" & E0 $10034^{\prime} 02.9^{\prime \prime}$ \\
\hline 6 & Wikki Warm Spring & N09 0 45'07.9" & E0 $10030^{\prime} 44.0^{\prime \prime}$ \\
\hline
\end{tabular}

Table 1: Location of Water Bodies in Yankari

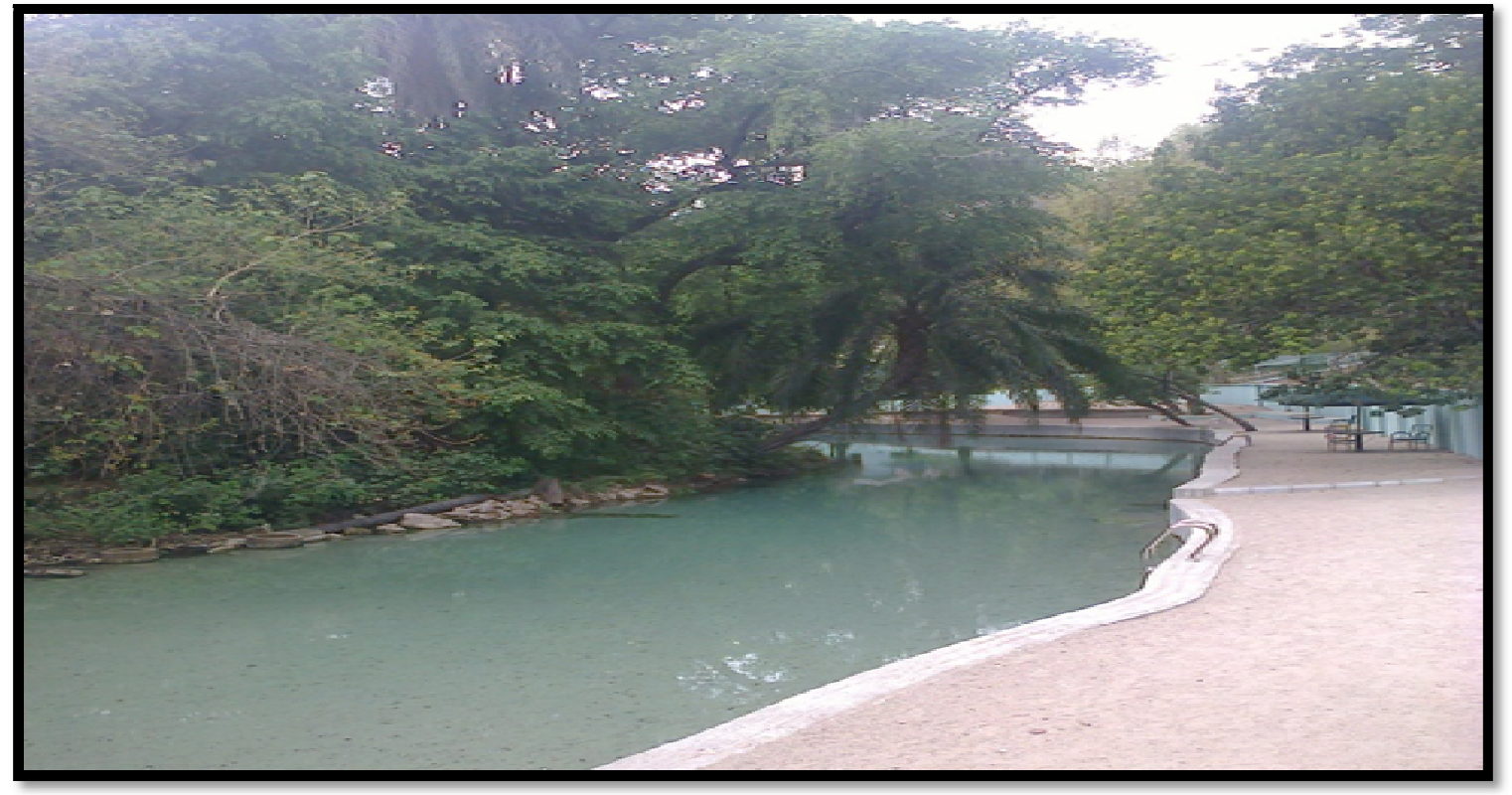

Plate 2: Wikki Warm Spring (The Only Explored and Developed Spring for Tourism)

Communities around the Yankari do not have immediate access to the Wikki spring neither do they have any pipe borne water connection for portable domestic water supply. Rather, majority of households (55\%) rely on hand dug wells, $30 \%$ on bore holes and only $10 \%$ on direct rainfall collection during the rainy season as illustrated in Figure 2 . Therefore, most of the households (85\%) that do not have access to boreholes suffer adverse scarcity of water in the dry season. 


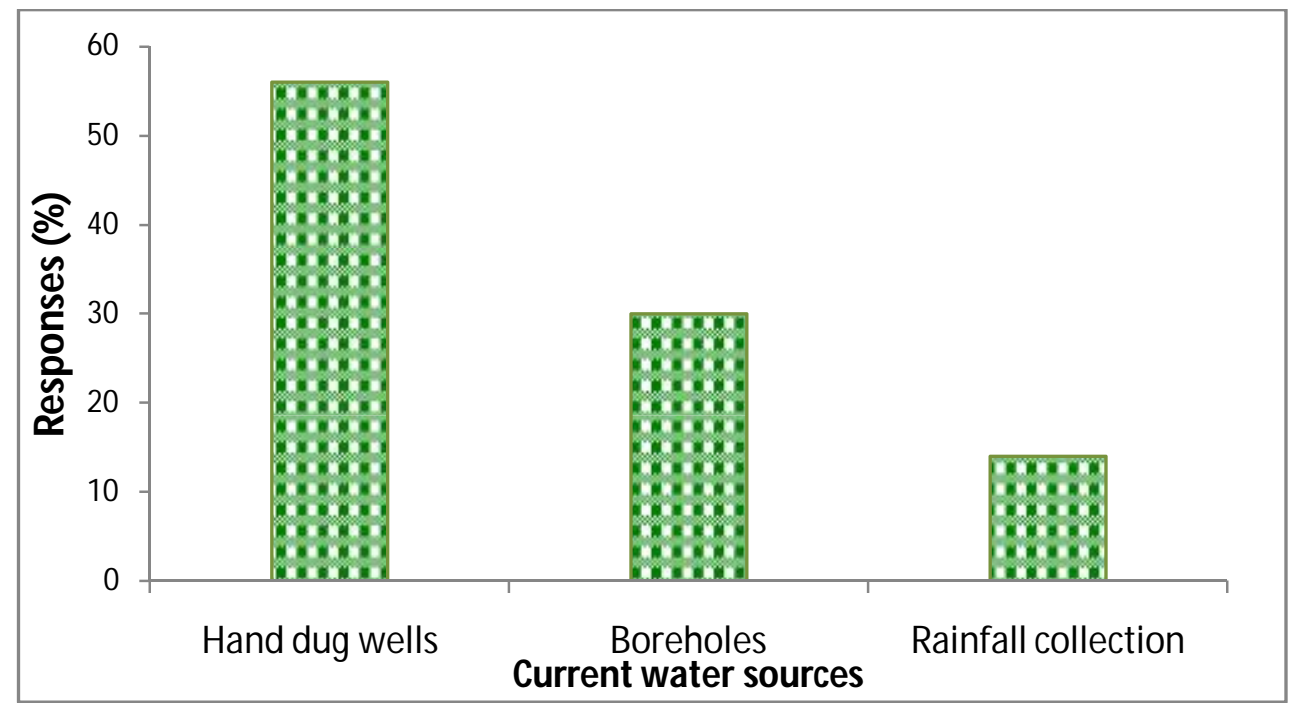

Figure 1: Responses on current water sources in Yankari by communities

Although the communities suffer from water scarcity, especially during the dry season, the Gaji river and the Yankari water springs (Wikki, Dimmil, Gwan, Nawulgo and Tungan Naliki) are potential sources of water for the surrounding local communities (see Plate 3). To support this observation, households were asked to mention a major potential source of water for their community. Figure 3 show that most households (75\%) indicated that the Gaji River is a potential source of water for their community. Others households indicated the springs as potential sources of water for their communities.Top is Wikki warm springas indicated by (10\%) of the sample surveyed, in other words, $40 \%$ of the respondents indicated that Wikki spring is the most potential source of water among the springs in the area. Wikkiis certainly the most popular of the springs and it is currently used staff of Yankari and other visitors and tourists for drinking and domestic purposes as well as by Fulani herdsmen (illegally) to water their animals.

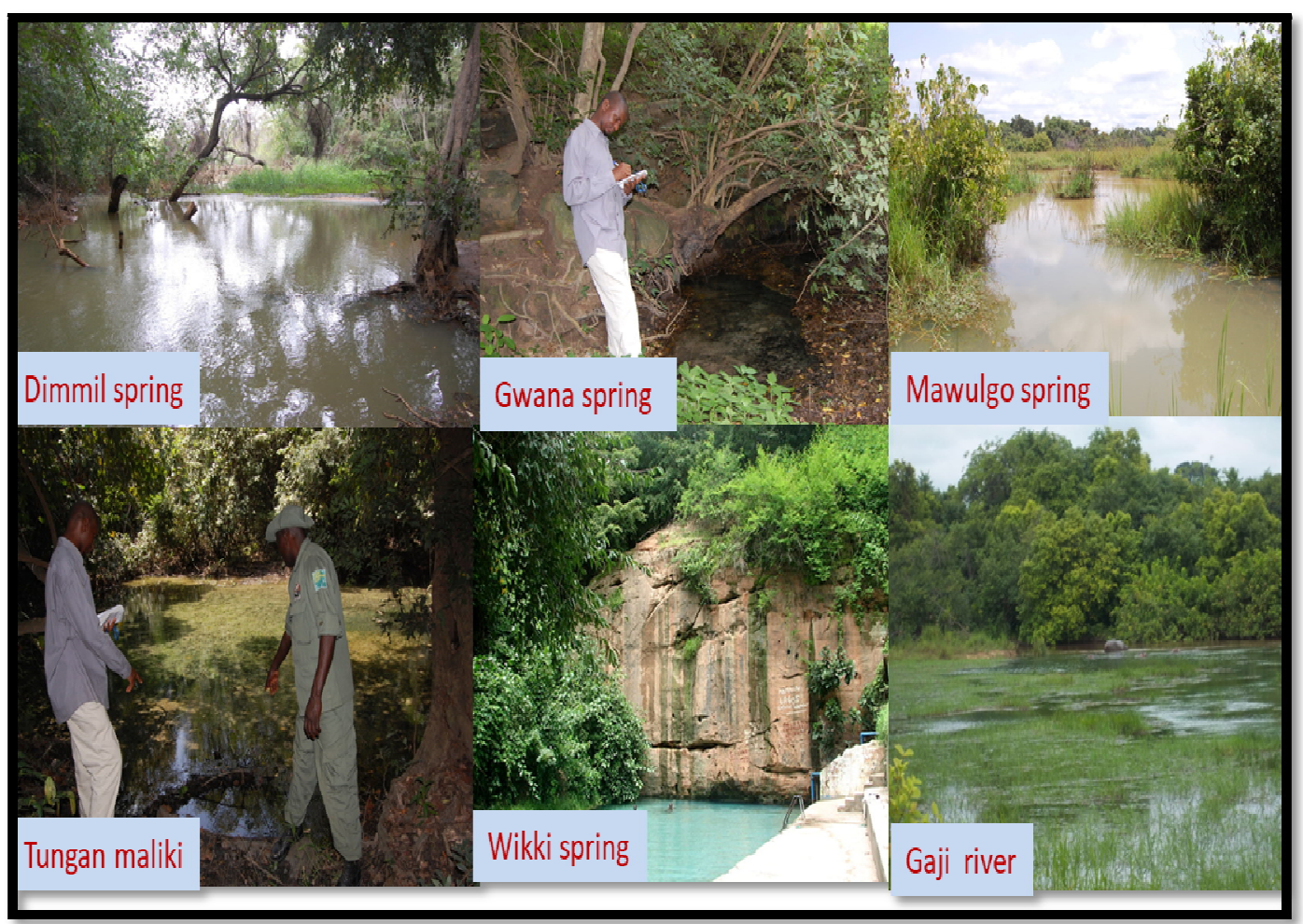

Plate 3: Six potential water sources in Yankari mentioned by the respondents.

(Pictures taken by authors during the survey, 2017). 


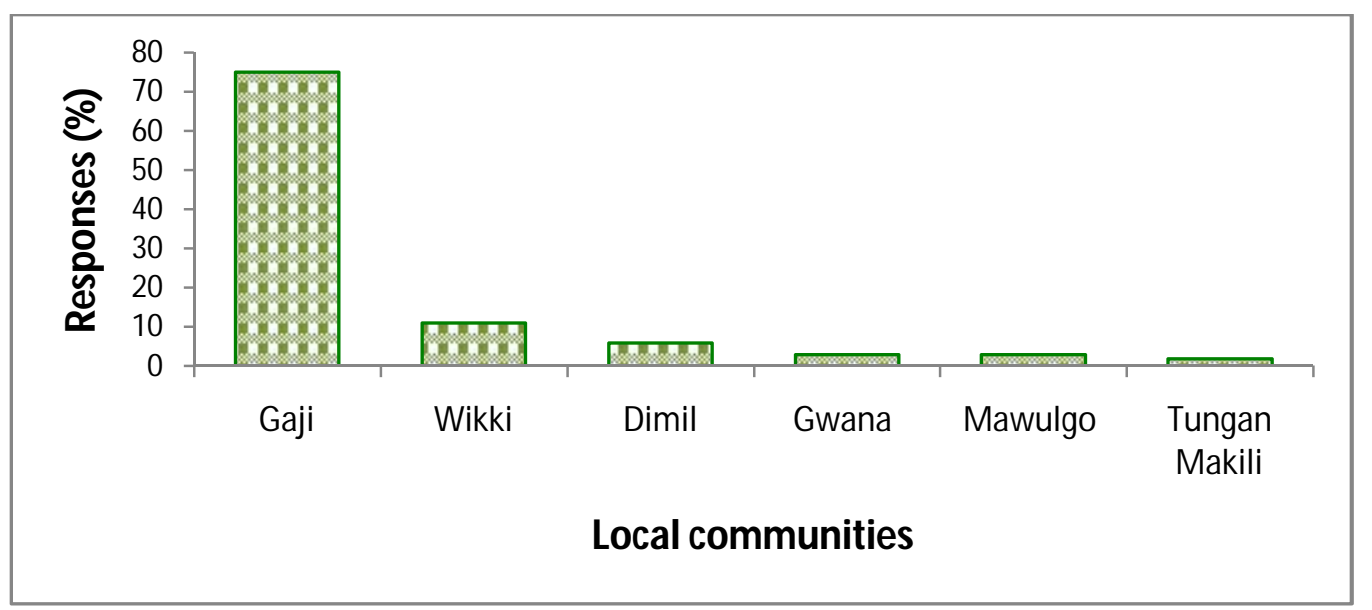

Figure 2: Responses On The Six Potential Sources Of Water In Yankari By Communities

These sources can be developed to supply water to the communities throughout the year (wet and dry season). As surface water sources, a treatment plant can be mounted and the water processed to ensure good quality for consumption. The processed water can be stored in reservoirs for onward delivery to household through pipe connections.

\section{Summary of findingsand conclusion}

The findings from this study suggest that Yankari have potential sources of water for domestic and other uses. Although the paper did not assess the quality of the water in the area, the quantity (volume) of water in the sources identified is a clear indication of potential sources of water supply in the area. The major findings from the paper are summarized thus:

- Gaji Riveris the most potential source of water for domestic uses in Yankari.The Yankari water springs are also potential sources of water for the surrounding local communities, considering physical quality of the water.

- The Wikki spring is the only one of the five springs that has been explored and it is highly utilized in Yankari.It is also the next potential source of water supply for the communities.

These findings are timely and important for the communities as well as Yankari. Therefore, joint efforts can be made to explore possibilities of developing these sources to ease the impact of acute scarcity of water in the area during dry periods. The study recommends further studies on the quantity and quality of water from these sources. An in-depth study should be conducted to measure the volumes of water in these river and springs. Water samples be taken for laboratory analysis the determine the concentration of physical, biological and chemical parameters in the water bodies.

\section{References}

i. Dabi, D.D., A.O. Nyong, A.A. Adepetu,\&V. Ihemegbulem (2008) 'Past, present and future adaptation by rural households of northern Nigeria.' In N. Leary, J. Adejuwon, V. Barros, I. Burton, J. Kulkarni\& R. Lasco (eds), Climate Change and Adaptation. Earthscan, London, UK. Chapter 8, 147-162.

ii. Fada, S.J. (2015) Processes and drivers of vegetation change in African drylands: a case study of Yankari Game Reserve, Nigeria. A thesis submitted for the degree of Doctor of Philosophy to Bangor University.168pp.

iii. Gaoue, O. G., \&Ticktin, T. (2007). "Patterns of Harvesting Foliage and Bark from the Multipurpose Tree Khaya Senegalensis in Benin: Variation across Ecological Regions and Its Impacts on Population Structure." Biological Conservation 137 (3): 424-36.

iv. Gonzalez, P. (2001) Desertification and a shift of forest species in the West African Sahel. Climate Research 17, 217228.

v. IUCN (2010)."Red List of Threatened Species: Nigeria”. International Union for Conservation of Nature.http:/ / www.iucnredlist.org/apps/ redlist/ search

vi. Okwa, O.O., Akinmolayan, F. I., Carter, V. \& Hurd, H. (2009). Transmissiondynamics ofmalaria in four selected ecological zones of Nigeria in the rainy season. Annals of African Medicine8(1): 1-9.

vii. Ouédraogo, A.\&Thiombiano, A. (2012). "Regeneration Pattern of Four Threatened Tree Species in Sudanian Savannas of Burkina Faso." Agroforestry Systems 86 (1): 35-48.

viii. Vörösmarty,C.J.,Douglas,E.M.,Green,P.A.\&Revenga,C.(2005)Geospatialindicatorsofemergingwaterstress:Anapplicationt oAfrica.Ambio34:230-236. 